\title{
Origin of Hexavalent Chromium in Drinking Water Wells from the Piedmont Aquifers of North Carolina
}

Avner Vengosh, ${ }^{* \dagger}{ }^{\dagger}$ Rachel Coyte, ${ }^{\dagger}$ Jonathan Karr, ${ }^{\dagger}$ Jennifer S. Harkness, ${ }^{\dagger}$ Andrew J. Kondash, Laura S. Ruhl, ${ }^{\ddagger}$ Rose B. Merola, ${ }^{\dagger}$ and Gary S. Dywer

${ }^{\dagger}$ Division of Earth and Ocean Sciences, Nicholas School of the Environment, Duke University, Durham, North Carolina 27708, United States

${ }^{\ddagger}$ Department of Earth Sciences, University of Arkansas at Little Rock, Little Rock, Arkansas 72204, United States

\section{Supporting Information}

ABSTRACT: Hexavalent chromium $[\mathrm{Cr}(\mathrm{VI})]$ is a known pulmonary carcinogen. Recent detection of $\mathrm{Cr}(\mathrm{VI})$ in drinking water wells in North Carolina has raised public concern about contamination of drinking water wells by nearby coal ash ponds. Here we report, for the first time, the prevalence of $\mathrm{Cr}$ and $\mathrm{Cr}(\mathrm{VI})$ in drinking water wells from the Piedmont region of central North Carolina, combined with a geochemical analysis to determine the source of the elevated $\mathrm{Cr}(\mathrm{VI})$ levels. We show that $\mathrm{Cr}(\mathrm{VI})$ is the predominant species of dissolved $\mathrm{Cr}$ in groundwater and elevated levels of $\mathrm{Cr}$ and $\mathrm{Cr}(\mathrm{VI})$ are found in wells located both near and far $(>30 \mathrm{~km})$ from coal ash ponds. The geochemical characteristics, including the overall chemistry, boron to chromium ratios, and strontium isotope $\left({ }^{87} \mathrm{Sr} /{ }^{86} \mathrm{Sr}\right)$ variations in groundwater with elevated $\mathrm{Cr}(\mathrm{IV})$ levels, are different from those of coal ash leachates. Alternatively, the groundwater chemistry and Sr isotope variations are consistent with water-rock interactions as the major source for $\mathrm{Cr}(\mathrm{VI})$ in groundwater. Our results indicate that $\mathrm{Cr}(\mathrm{VI})$ is most likely naturally occurring and ubiquitous in groundwater from the Piedmont region in the eastern United States, which could pose health risks to residents in the region who consume well water as a major drinking water source.

\section{INTRODUCTION}

Since the early findings of hexavalent chromium $[\mathrm{Cr}(\mathrm{VI})]$ in drinking water in the Hinkley community of San Bernardino County, California, presumably from $\mathrm{Cr}(\mathrm{VI})$ additives at watercooling towers from gas compressor facilities, there has been a persistent controversy about the sources of $\mathrm{Cr}(\mathrm{VI})$ in groundwater and its human health impacts. ${ }^{1}$ Most $\mathrm{Cr}$ in aquatic systems occurs as either the trivalent chromium [Cr(III)] cation $\mathrm{Cr}^{3+}$ or $\mathrm{Cr}(\mathrm{VI})$ oxyanions, such as the monovalent $\mathrm{HCrO}_{4}{ }^{-}$and divalent $\mathrm{CrO}_{4}{ }^{2-}$ species. ${ }^{2-4}$ All $\mathrm{Cr}(\mathrm{VI})$ compounds are strong oxidizing agents and are recognized by the World Health Organization (WHO) as "carcinogenic to humans (Group 1)", 15 and $\mathrm{Cr}(\mathrm{VI})$ is recognized as a pulmonary carcinogen. ${ }^{5-14}$ However, the U.S. Environmental Protection Agency (EPA) does not regulate individual $\mathrm{Cr}$ species, and the drinking water standard includes only total $\mathrm{Cr}\left[\mathrm{Cr}_{\mathrm{T}}\right.$, maximum contaminant level (MCL) of 100 $\mu \mathrm{g} / \mathrm{L}] ;{ }^{4}$ the most updated $2003 \mathrm{WHO}$ guidelines for drinking water include only total $\mathrm{Cr}$ with an upper limit of $50 \mu \mathrm{g} / \mathrm{L}^{15}$ The absence of $\mathrm{Cr}(\mathrm{VI})$ from the drinking water regulations was explained by analytical limitation and the assumption that the speciation of $\mathrm{Cr}$ favors the predominance of the less toxic Cr(III) under typical environmental conditions. ${ }^{4,15}$ To date, only the state of California has issued a specific MCL of $10 \mu \mathrm{g} /$

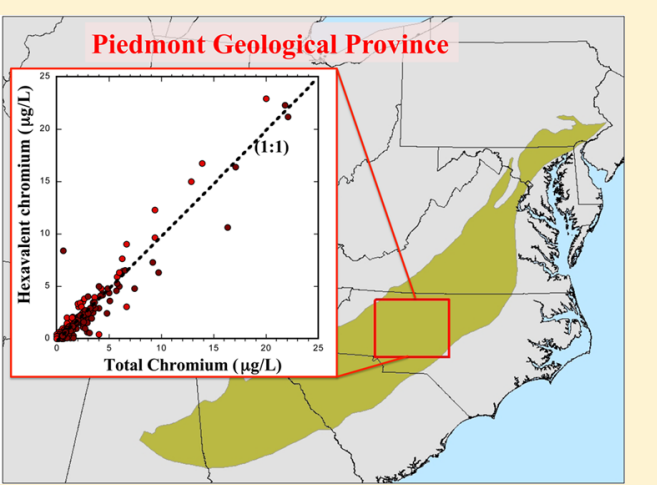

$\mathrm{L}$ and a public health goal (PHG) of $0.02 \mu \mathrm{g} / \mathrm{L}$ for $\mathrm{Cr}(\mathrm{VI})$ in drinking water. ${ }^{16}$

It is commonly assumed that the occurrence of $\mathrm{Cr}(\mathrm{VI})$ in drinking water wells is directly associated with human activities, and any detection of $\mathrm{Cr}(\mathrm{VI})$ infers anthropogenic contamination. ${ }^{415}$ However, recent reports have established that naturally occurring $\mathrm{Cr}(\mathrm{VI})$ is prevalent in groundwater from specific aquifer systems composed of ultramafic rocks, known to be enriched with $\mathrm{Cr}$ relative to other rock types. ${ }^{17}$ Elevated $\mathrm{Cr}(\mathrm{VI})$ levels were reported in groundwater associated with ultramafic aquifers in California, ${ }^{18-21}$ Arizona, ${ }^{22}$ Mexico, ${ }^{23}$ Argentina, ${ }^{24}$ Brazil, $^{25}$ Italy, $^{26}$ and Greece. ${ }^{27}$ Experimental work demonstrated that the presence of manganese oxide minerals within ultramafic- and serpentinite-derived soils and/or sediments can trigger the oxidation of $\mathrm{Cr}$, leading to the presence of naturally occurring $\mathrm{Cr}(\mathrm{VI})$ in aquifers. ${ }^{28}$

Recent detection of $\mathrm{Cr}(\mathrm{VI})$ in drinking water wells near coal ash ponds in North Carolina ${ }^{29}$ has been attributed to leaking from nearby coal ash ponds because an elevated $\mathrm{Cr}$ levels have been reported in coals and coal ash residuals (CCRs). ${ }^{30-33}$ This

Received: September 4, 2016

Revised: September 29, 2016

Accepted: September 30, 2016

Published: October 26, 2016 


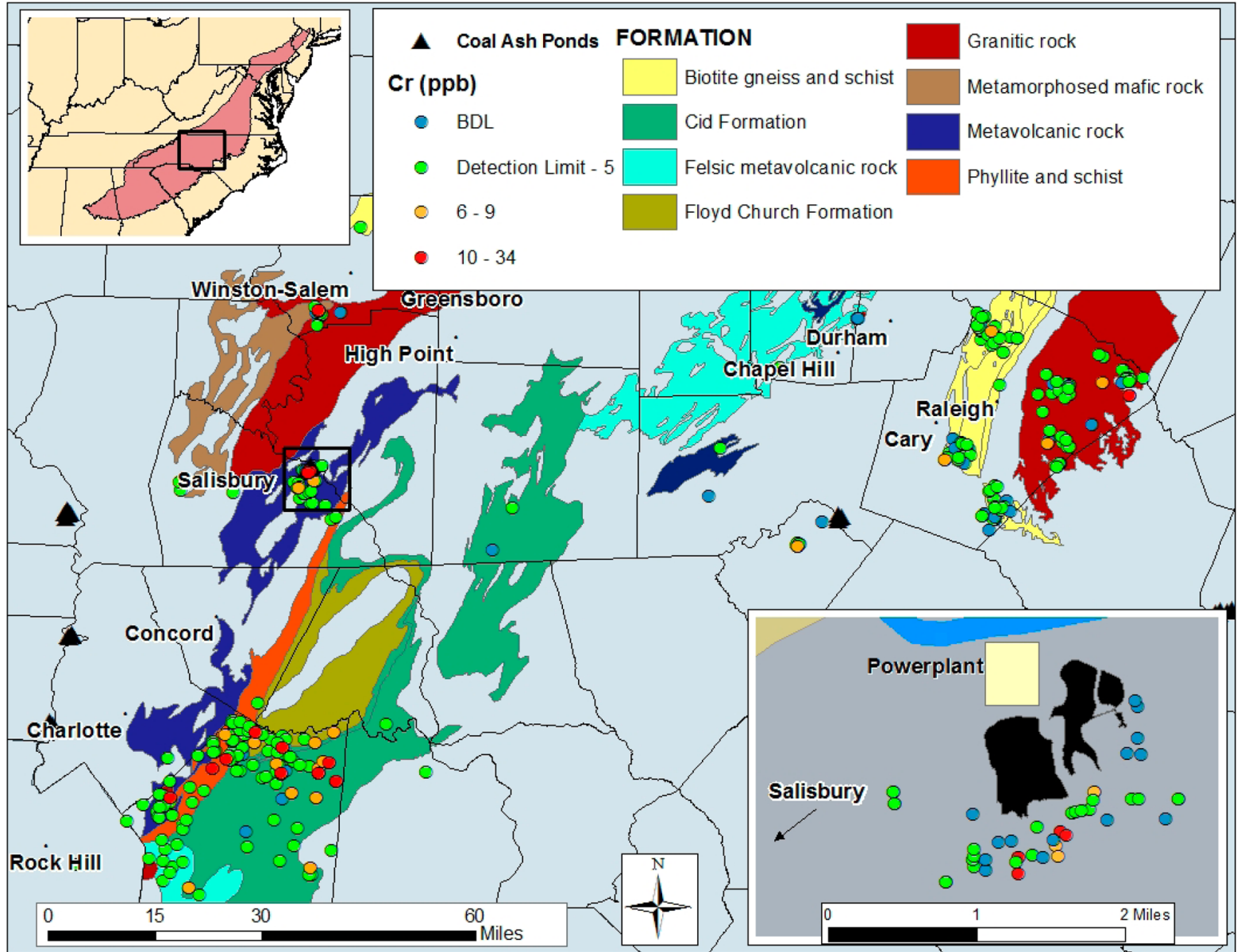

Figure 1. Distribution of total $\mathrm{Cr}$ concentrations (ranked by color, in micrograms per liter) in drinking water wells, coal ash ponds, and selective geological formations in the Piedmont region of North Carolina. The small inset map at the top left shows the distribution of the Piedmont geology in the southeastern United States. The bottom inset map shows the distribution of Cr near coal ash ponds close to Salisbury, NC. The felsic metavolcanic rock and granitic rock categories are primarily felsic formations. The Cid, Floyd Church, metamorphosed mafic rock, and metavolcanic formations are of mixed character with varying levels of mafic components. The biotite gneiss and schist and phyllite and schist categories are characterized as general metamorphic bodies. The $\mathrm{Cr}$ concentrations in groundwater from the different formations are reported in Table S2. Geological data and location of coal ash ponds were retrieved from U.S. Geological Survey database ${ }^{44}$ and Southern Alliance for Clean Energy. ${ }^{45}$

study aims to determine whether coal ash ponds are causing the $\mathrm{Cr}(\mathrm{VI})$ contamination in local aquifers or if $\mathrm{Cr}(\mathrm{VI})$ is naturally occurring and ubiquitously distributed in groundwater across the Piedmont region. The study is based on systematic measurements of $\mathrm{Cr}_{\mathrm{T}}$ and $\mathrm{Cr}(\mathrm{VI})$ in groundwater from different aquifers and varying distances from coal ash ponds in the Piedmont region of North Carolina, combined with geochemical and strontium isotope tracers known to be indicative of coal ash contamination and water-rock interactions. ${ }^{3-36}$ Previous studies have observed elevated Sr $(>150 \mu \mathrm{g} / \mathrm{L})$ and B $(>100 \mu \mathrm{g} / \mathrm{L})$ levels and distinct $\mathrm{Sr}$ isotope ratios $\left({ }^{87} \mathrm{Sr} /{ }^{86} \mathrm{Sr}=0.7095-0.7120\right)$ in effluent discharged from coal ash ponds and in contaminated surface and groundwater. ${ }^{34-36}$ The $\mathrm{Sr}$ and B tracers are particularly useful for delineating the release of coal ash pond water because they are sensitive to very small contributions of contaminated water to the environment. ${ }^{35,36}$ We hypothesize that $\mathrm{Cr}(\mathrm{VI})$ contamination from coal ash ponds will be associated with modification of the chemical and isotope compositions of the groundwater toward a coal ash geochemical signature. ${ }^{34-36}$

\section{MATERIALS AND METHODS}

Water samples in the study were collected from domestic groundwater wells in central North Carolina and were analyzed for major and trace elements $(n=376)$. A subset of these groundwater samples were analyzed for $\mathrm{Cr}(\mathrm{VI})(n=77)$ and stable isotopes of strontium $\left({ }^{87} \mathrm{Sr} /{ }^{86} \mathrm{Sr} ; n=45\right)$. Water samples were collected before any treatment systems following standard methods. ${ }^{37}$ Anions were measured by ion chromatography (IC) on a Dionex IC DX-2100 instrument; major cations were measured by direct current plasma optical emission spectrometry (DCP-OES) and trace elements by a VG PlasmaQuad-3 inductively coupled plasma mass spectrometer (ICP-MS). The DCP and ICP-MS instruments were calibrated to the National Institute of Standards and Technology 1643e standard. The detection limit of ICP-MS for each element was determined by dividing 3 times the standard deviation of repeated blank measurements by the slope of the external standard. $\mathrm{Cr}(\mathrm{VI})$ was measured as chromate according to a modified version of U.S. EPA Method 218.6. ${ }^{38}$ This method is based on anion exchange chromatography on a Thermo Scientific Dionex IonPac AS7 column $(4 \mathrm{~mm} \times 250 \mathrm{~mm})$ with a method detection limit (MDL) for chromate of $0.004 \mu \mathrm{g} / \mathrm{L}$ and a reporting limit of $0.012 \mu \mathrm{g} / \mathrm{L}$ (see the text of the Supporting 
Information). Strontium isotopes were analyzed by thermal ionization mass spectrometry (TIMS) on a ThermoFisher Triton instrument at Duke University. The external reproducibility of ${ }^{87} \mathrm{Sr} /{ }^{86} \mathrm{Sr}$ ratios was comparable to standard NIST987 $(0.710265 \pm 0.000006)$.

Geospatial analysis of data was conducted using ArcMap version 10.3.1. The background on the hydrogeology and geological map is provided in the text of the Supporting Information. Statistical analyses were performed using $\mathrm{R}$ (version 3.2.0). All correlations were Spearman nonparametric correlations, and the reported $r$ is the Spearman rank coefficient, rho. The nonparametric Wilcoxon rank sum test was used to determine if concentration mean ranks differ between different populations.

\section{RESULTS AND DISCUSSION}

Geochemical Characteristics of Piedmont Groundwater. Total $\mathrm{Cr}\left(\mathrm{Cr}_{\mathrm{T}}\right)$ concentrations ranged from below the reporting limit $(0.0016 \mu \mathrm{g} / \mathrm{L})$ to $33.8 \mu \mathrm{g} / \mathrm{L}$ (Figure 1$)$. In the subset of samples $(n=77)$ analyzed for $\mathrm{Cr}(\mathrm{VI}), \mathrm{Cr}(\mathrm{VI})$ concentrations varied from below the reporting limit $(0.012$ $\mu \mathrm{g} / \mathrm{L}$ ) to $22.9 \mu \mathrm{g} / \mathrm{L}$ and were highly correlated to $\mathrm{Cr}_{\mathrm{T}}$ [slope of $\sim 1 ; r^{2}=0.93 ; p<0.001$ (Figure 2)]. Our data are consistent

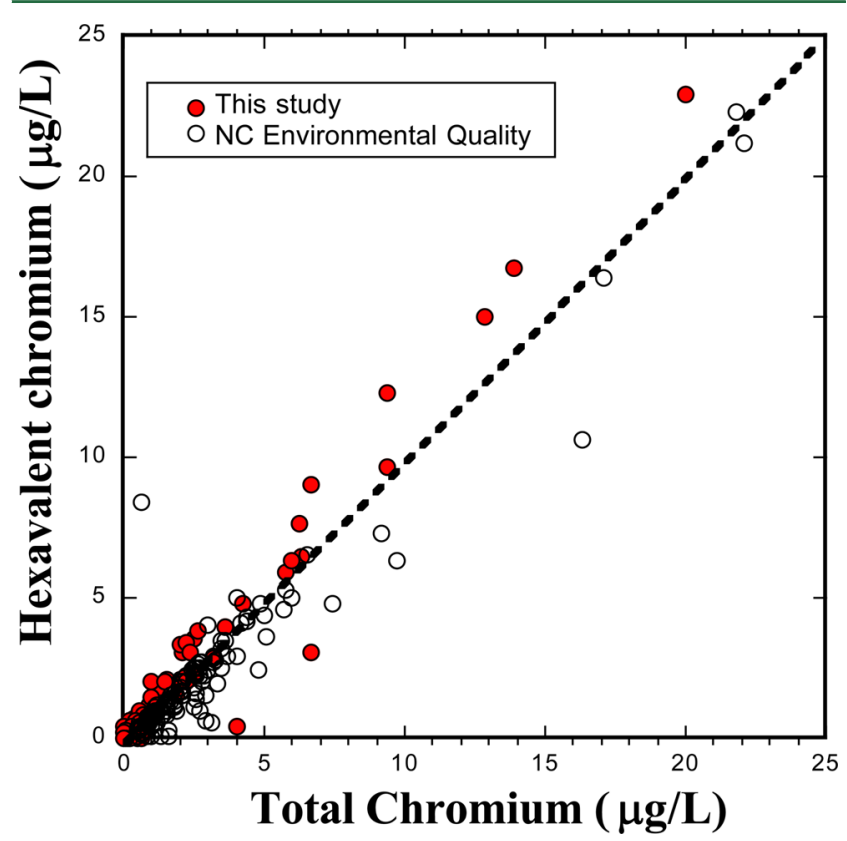

Figure 2. Hexavalent chromium concentration vs total $\mathrm{Cr}$ concentration in groundwater analyzed in this study (red circles) and reported by the North Carolina Department of Environmental Quality $^{25}(\mathrm{O})$. Note the high correlation of $\mathrm{Cr}(\mathrm{VI})$ to $\mathrm{Cr}_{\mathrm{T}}$ in both data sets with an $r^{2}$ of $0.93(p<0.001 ; n=77)$ reported in this study and an $r^{2}$ of $0.90(p<0.001 ; n=129)$ in NC-DEQ data. The $\sim 1: 1$ ratio in most of the samples indicates that $\mathrm{Cr}(\mathrm{VI})$ is the predominant species of dissolved $\mathrm{Cr}$ in the Piedmont groundwater.

with data reported by the North Carolina Department of Environmental Quality ${ }^{25}$ for residents near coal ash impoundments $(n=129)$ that show the same range of $\mathrm{Cr}(\mathrm{VI})$ concentrations and a high correlation between $\mathrm{Cr}(\mathrm{VI})$ and $\mathrm{Cr}_{\mathrm{T}}$ [slope of $\sim 0.9 ; r^{2}=0.90 ; p<0.001$ (Figure 2)]. The average $\mathrm{Cr}(\mathrm{VI}) / \mathrm{Cr}_{\mathrm{T}}$ ratio of $\sim 1$ indicates that $\mathrm{Cr}(\mathrm{VI})$ is the predominant species of dissolved $\mathrm{Cr}$ in groundwater and accounts for nearly all of the dissolved Cr. While the NC-DEQ data are restricted to wells located near coal ash ponds, our data collection included wells located far (up to $75 \mathrm{~km}$ ) from coal ash impoundments (Figure 1).

Strontium concentrations in the groundwater ranged from the detection limit $(0.25 \mu \mathrm{g} / \mathrm{L})$ to $3426 \mu \mathrm{g} / \mathrm{L}$, with low $\mathrm{Sr} / \mathrm{Ca}$ ratios $[<0.006$ (Figure 3A)]. Groundwater from a $\mathrm{Cr}(\mathrm{VI})$-rich
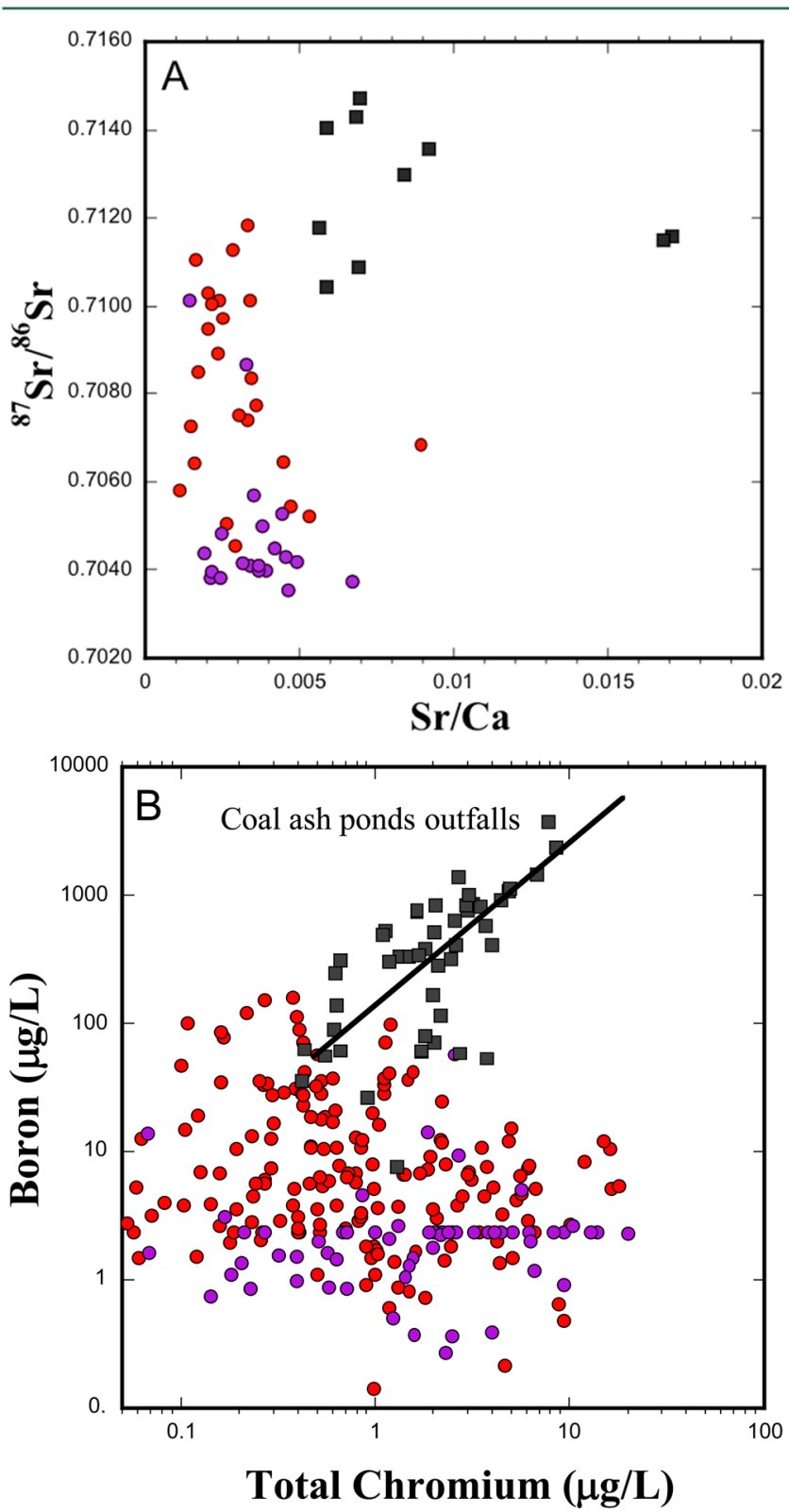

Figure 3. Variations of (A) ${ }^{87} \mathrm{Sr} /{ }^{86} \mathrm{Sr}$ vs $\mathrm{Sr} / \mathrm{Ca}$ and (B) B vs total $\mathrm{Cr}$ (log scale) in groundwater from the Piedmont region (red and purple circles) as compared to that of effluent discharge from coal ash ponds' outfalls in North Carolina (black squares; data from ref 31). The data show systematically lower ${ }^{87} \mathrm{Sr} /{ }^{86} \mathrm{Sr}, \mathrm{Sr} / \mathrm{Ca}$, and $\mathrm{B} / \mathrm{Cr}$ ratios in groundwater than in coal ash effluents. Groundwater from aquifers composed of metavolcanic rocks (purple circles) is characterized by distinctively lower ${ }^{87} \mathrm{Sr} /{ }^{86} \mathrm{Sr}, \mathrm{Sr} / \mathrm{Ca}$, and B contents relative to those of groundwater from other aquifers and coal ash effluents. The combined data indicate that the chemistry of the Piedmont groundwater is different from the composition of coal ash waters, particularly for groundwater from metavolcanic aquifers that are located near coal ash ponds $(n=16)$, thus ruling out the possibility of the contamination of drinking water wells by coal ash ponds. 
metavolcanic aquifer in Rowan County located near a coal ash pond $(n=16)$ (Figure 1$)$ and aquifers containing mafic rocks from other counties in the Piedmont region $(n=7)$ had low ${ }^{87} \mathrm{Sr} /{ }^{86} \mathrm{Sr}$ ratios $[0.7041 \pm 0.0005$ (Figure 3A) $]$. Groundwater from the other aquifers showed large variations in ${ }^{87} \mathrm{Sr} /{ }^{86} \mathrm{Sr}$ (a range of $0.7052-0.7119$ ), with higher ${ }^{87} \mathrm{Sr} /{ }^{86} \mathrm{Sr}$ ratios in the felsic and phyllite and schist aquifers [0.7074-0.7119 (Figure S3)]. Boron concentrations from the Piedmont region were low (a range of $0.09-159.2 \mu \mathrm{g} / \mathrm{L}$, median of $3.7 \mu \mathrm{g} / \mathrm{L}$ ) with low $\mathrm{B} / \mathrm{Cr}_{\mathrm{T}}$ ratios [median of 8.6 (Figure $3 \mathrm{~B}$ )]. In particular, groundwater from wells from the metavolcanic aquifer near coal ash ponds with high $\mathrm{Cr}(\mathrm{VI})$ concentrations in Rowan County (see the inset map in Figure 1) had systematically low B concentrations [median of $2.3 \pm 17.3 \mu \mathrm{g} / \mathrm{L}$ (Figure S4)] and low $\mathrm{B} / \mathrm{Cr}_{\mathrm{T}}$ ratios $(<200)$.

Tracing the Source of Hexavalent Chromium. Previous studies have shown that coal ash effluents and coal ashcontaminated groundwater have high concentrations of B and $\mathrm{Sr}$ with distinctive radiogenic $\mathrm{Sr}$ isotope ratios, which are different in some cases from those in natural waters. ${ }^{34-36,39-41}$ Waters impacted by CCR effluents typically have high B and $\mathrm{Sr}$ concentrations (above background levels of 100 and $150 \mu \mathrm{g} / \mathrm{L}$, respectively), high $\mathrm{Sr} / \mathrm{Ca}$ ratios $(>0.006)$, and high ${ }^{87} \mathrm{Sr} /{ }^{86} \mathrm{Sr}$ ratios $(>0.70975))^{34-36}$ In shallow groundwater monitoring wells around coal ash ponds in North Carolina, the B levels reached $5000 \mu \mathrm{g} / \mathrm{L} .^{36}$ The low $\mathrm{B}$ concentrations and $\mathrm{B} / \mathrm{Cr}_{\mathrm{T}}$, $\mathrm{Sr} / \mathrm{Ca} \quad(<0.006)$, and ${ }^{87} \mathrm{Sr} /{ }^{86} \mathrm{Sr}$ ratios of the $\mathrm{Cr}(\mathrm{VI})$-rich groundwater in this study, including wells located near $(<5$ $\mathrm{km}$ ) a coal ash pond, are inconsistent with the geochemistry expected for CCR-impacted water (Figure 3A). The low ${ }^{87} \mathrm{Sr} /{ }^{86} \mathrm{Sr}$ ratios observed in the groundwater in Rowan County are consistent with a nonradiogenic $\mathrm{Sr}$ isotope composition that is typical for the mafic rocks that are prevalent in this aquifer, indicating that $\mathrm{Sr}$ is derived from water-rock interactions and not from coal ash pond contamination. Higher ${ }^{87} \mathrm{Sr} /{ }^{86} \mathrm{Sr}$ ratios were observed in felsic aquifers and other nonmafic aquifers (Figure S3); however, these aquifers were not associated with high $\mathrm{Cr}(\mathrm{VI})$ and in many cases were located far from coal ash ponds.

Data from coal ash pond effluents in North Carolina ${ }^{34}$ show that $\mathrm{B}$ is strongly correlated to $\mathrm{Cr}_{\mathrm{T}}\left[r^{2}=0.68 ; p<0.001\right.$ (Figure $3 \mathrm{~B})$ ], with high $\mathrm{B} / \mathrm{Cr}_{\mathrm{T}}$ ratios of $\sim 297$. In contrast, all groundwater from the Piedmont region had much lower $\mathrm{B}$ concentrations and $\mathrm{B} / \mathrm{Cr}_{\mathrm{T}}$ ratios. In particular, groundwater wells in Rowan County near the coal ash pond with a high $\mathrm{Cr}(\mathrm{VI})$ concentration had $\mathrm{B}$ levels and $\mathrm{B} / \mathrm{Cr}_{\mathrm{T}}$ ratios $2-3$ orders of magnitude lower than those of coal ash pond effluents from North Carolina (Figure 3B).

In addition to the groundwater in Rowan County, samples were collected from wells in formations containing mafic rocks located in counties that did not have any coal ash ponds. Elevated $\mathrm{Cr}(\mathrm{VI})$ concentrations were detected in wells from mafic-rich aquifers in Forsyth County that are located more than $30 \mathrm{~km}$ from a coal ash pond. These samples had elevated $\mathrm{Cr}(\mathrm{VI})$ concentrations of up to $10 \mu \mathrm{g} / \mathrm{L}$ with $\mathrm{Sr} / \mathrm{Ca}(<0.006)$, $\mathrm{B} / \mathrm{Cr}_{\mathrm{T}}(<20)$, and ${ }^{87} \mathrm{Sr} /{ }^{86} \mathrm{Sr}$ ratios similar to those of the maficcontaining aquifer near the coal ash ponds in Rowan County.

It is important to note that coal ash effluents that discharge from coal ash ponds in NC have high concentrations of sulfate, arsenic, selenium, molybdenum, and thallium relative to those of natural waters, ${ }^{34}$ which are not present in the groundwater near coal ash ponds tested in this study. Furthermore, the range of $\mathrm{Cr}_{\mathrm{T}}$ concentrations found in coal ash effluents $[0.4-8.6 \mu \mathrm{g} / \mathrm{L}$
(Figure S5)] is lower than those measured in nearby groundwater. Overall, the geochemical and isotopic data clearly indicate that the drinking water wells tested in this study are not impacted by CCR effluents, and therefore, the coal ash ponds are not a likely source of the elevated $\mathrm{Cr}_{\mathrm{T}}$ and $\mathrm{Cr}(\mathrm{VI})$ concentrations found in the Piedmont groundwater. These results are further supported by the presence of $\mathrm{Cr}(\mathrm{VI})$-rich groundwater that has similar geochemistry in wells located more than $30 \mathrm{~km}$ from a coal ash pond (Figure 1 and Figure S2). Total $\mathrm{Cr}$ concentrations were not strongly correlated with distance $(r=0.09)$ but showed a significant $(p<0.05)$ increase with distance from coal ash ponds, and concentrations of up to $34 \mu \mathrm{g} / \mathrm{L}$ were found in wells more than $50 \mathrm{~km}$ from the nearest coal ash pond. These results indicate that high $\mathrm{Cr}$ concentrations can be found in wells located far from coal ash ponds, which is inconsistent with the expected trend if coal ash ponds were the source of $\mathrm{Cr}$ contamination in nearby groundwater. The geospatial analysis therefore supports the conclusions drawn from the geochemical data.

Distribution of Chromium in the Piedmont Aquifers. While our geochemical analysis rules out contamination from nearby coal ash ponds, we present evidence of a geogenic source of $\mathrm{Cr}$ and $\mathrm{Cr}(\mathrm{VI})$ to drinking water aquifers. First, we show that $\mathrm{Cr}$ [and $\mathrm{Cr}(\mathrm{VI})]$ can be found throughout the different aquifers of the Piedmont region (Figure 1). Second, the association of ${ }^{87} \mathrm{Sr} /{ }^{86} \mathrm{Sr}$ ratios with aquifer lithology (Figure S3) indicates that the local aquifer rocks are the source of dissolved $\mathrm{Sr}$ and apparently $\mathrm{Ca}$ in groundwater, given the high correlation between $\mathrm{Sr}$ and $\mathrm{Ca}$ (Figure S6). Third, the association of $\mathrm{Ca}$ and $\mathrm{Cr}$ in groundwater from some aquifers (Figure S7) suggests that $\mathrm{Cr}$, like $\mathrm{Ca}$, is derived from waterrock interactions rather than an external (i.e., anthropogenic) source. The distribution of $\mathrm{Cr}_{\mathrm{T}}$ varies among the different types of lithology (Figure S8), with the highest to lowest median $\mathrm{Cr}_{\mathrm{T}}$ values observed in groundwater from the Floyd Church Formation, Cid Formation, mafic metavolcanic, phyllite and schist, biotite gneiss schist, felsic mica gneiss, felsic metamorphic, and granitic rocks, respectively (Table S2). The data show that groundwater from intermediate or mixed mafic metavolcanic formations has $\mathrm{Cr}_{\mathrm{T}}$ concentrations $(p<0.05)$ significantly higher than those of groundwater from felsic formations (Table S3). These results are consistent with previous studies that have shown high $\mathrm{Cr}(\mathrm{VI})$ concentrations in groundwater from ultramafic rocks, ${ }^{18-27}$ yet the data presented in this study infer $\mathrm{Cr}(\mathrm{VI})$ prevalence in groundwater from aquifers composed of metamorphic mafic rocks and even felsic rocks, which are highly common in the Piedmont region of the eastern United States. ${ }^{42}$

Environmental Health Implications. Assuming that $\mathrm{Cr}(\mathrm{VI})$ is the predominant $\mathrm{Cr}$ species in drinking water wells, we show that only 14 of 376 wells $(\sim 4 \%)$ had $\mathrm{Cr}_{\mathrm{T}}$ above the California MCL limit of $10 \mu \mathrm{g} / \mathrm{L}$. At the same time, only 8 of $77(\sim 10 \%)$ wells had $\mathrm{Cr}(\mathrm{VI})$ levels below the detection level $(0.004 \mu \mathrm{g} / \mathrm{L})$, meaning that $90 \%$ of the study wells had detectable $\mathrm{Cr}(\mathrm{VI})$, and furthermore, all of the detectable $\mathrm{Cr}(\mathrm{VI})$ was above the California PHG of $0.02 \mu \mathrm{g} / \mathrm{L}$. While our sample collection was conducted in the Piedmont region of North Carolina, the distribution of the Piedmont rocks extends to other states in the eastern United States (see the top inset map in Figure 1), and a large population is potentially consuming drinking water with detectable and, in some cases, high $\mathrm{Cr}(\mathrm{VI})$ levels. Given the global distribution of aquifers composed of mafic and igneous rocks, ${ }^{43}$ we hypothesize that 
the occurrence of $\mathrm{Cr}(\mathrm{VI})$ in shallow drinking water wells is much more widespread than previously thought, with possibly millions in the eastern United States and other parts of the world directly exposed to detectable $\mathrm{Cr}(\mathrm{VI})$ from drinking water wells. The lack of a national Cr(VI) standard for drinking water ${ }^{4}$ impedes a large scale evaluation of the distribution of $\mathrm{Cr}(\mathrm{VI})$ in groundwater systems. Monitoring and screening for $\mathrm{Cr}(\mathrm{VI})$ levels in public and private wells are therefore essential for protecting human health in the Piedmont region and beyond.

\section{ASSOCIATED CONTENT}

\section{S Supporting Information}

The Supporting Information is available free of charge on the ACS Publications website at DOI: 10.1021/acs.estlett.6b00342.

Eight figures, three tables, information about the analytical procedure of hexavalent chromium, and background on the hydrogeology of the Piedmont area (PDF)

\section{AUTHOR INFORMATION}

\section{Corresponding Author}

*E-mail: vengosh@duke.edu. Phone: 919-681-8050. Fax: 919684-5833.

Notes

The authors declare no competing financial interest.

\section{ACKNOWLEDGMENTS}

We gratefully acknowledge financial support from the Foundation for the Carolinas to the Nicholas School of the Environment, Duke University, and a grant from the North Carolina Water Resources Research Institute (NC-WRRI).

\section{REFERENCES}

(1) Fryzek, J. P.; Mumma, M. T.; McLaughlin, J. K.; Henderson, B. E.; Blot, W. J. Cancer Mortality in Relation to Environmental Chromium Exposure. J. Occup. Environ. Med. 2001, 43, 635-640.

(2) Sengupta, A. D.; Clifford, S.; Subramonian, S. Chromate IonExchange Process at alkaline pH. Water Res. 1986, 20, 1177-1184.

(3) Bartlett, R. J. Chromium Cycling in Soils and Water: Links, Gaps, and Methods. Environ. Health Perspect 1991, 92, 17-24.

(4) U.S. Environmental Protection Agency (US-EPA). 2016. Basic Information about Chromium in Drinking Water. (http://water.epa. gov/drink/contaminants/basicinformation/chromium.cfm) (accessed September, 23, 2016).

(5) Barceloux, D. G.; Barceloux, D. Chromium. J. Toxicol., Clin. Toxicol. 1999, 37, 173-194.

(6) Cohen, M. D.; Kargacin, B.; Klein, C. B.; Costa, M. Mechanisms of chromium carcinogenicity and toxicity. Crit. Rev. Toxicol. 1993, 23, 255-281.

(7) Agency for Toxic Substances and Disease Control (ATSDR). ATSDR's Toxicological Profiles: Chromium; Lewis Publishers, CRC Press, Inc.: Boca Raton, FL, 1997.

(8) International Agency for Research on Cancer (IARC). Chromium, Nickel and Welding Fumes; IARC Monographs on the Evaluation of Carcinogenic Risks to Humans; IARC: Lyon, France, 1990; No. 49, pp 1-648 (http://monographs.iarc.fr/ENG/Monographs/vol100C/ 100C-04-Index-tables.php) (accessed Septermber, 23, 2016).

(9) Saha, R.; Nandi, R.; Saha, B. Sources and toxicity of hexavalent chromium. J. Coord. Chem. 2011, 64, 1782-1806.

(10) Occupational Safety and Health Administration (OSHA). Occupational exposure to hexavalent chromium. Fed. Regist. 2006, 71, 10099-10385.
(11) Toxicological Review of Hexavalent Chromium. EPA/635/R10/004A; U.S. Environmental Protection Agency: Washington, DC, 2010.

(12) Beaumont, J. J.; Sedman, R. M.; Reynolds, S. D.; Sherman, C. D.; Li, L. H.; Howd, R. A.; Sandy, M. S.; Zeise, L.; Alexeeff, G. V. Cancer mortality in a Chinese population exposed to hexavalent chromium in drinking water. Epidemiology 2008, 19, 12-23.

(13) Smith, A. H.; Steinmaus, C. M. Health effects of arsenic and chromium in drinking water: recent human findings. Annu. Rev. Public Health 2009, 30, 107-122.

(14) Rowbotham, A. L.; Levy, L. S.; Shuker, L. K. Chromium in the environment: an evaluation of exposure of the UK general population and possible adverse health effects. J. Toxicol. Environ. Health, Part B 2000, 3, 145-178.

(15) World Health Organization (WHO). Chromium in drinkingwater. Guidelines for drinking-water quality, 2nd ed.; World Health Organization: Geneva, 2004; Vol. 2 (health criteria and other supporting information).

(16) California Chromium-6 Drinking Water MCL (http://www. waterboards.ca.gov/drinking_water/certlic/drinkingwater/ Chromium6.shtml) (accessed September 23, 2016).

(17) Guertin, J., Jacobs, J. A., Avakian, C. P., Eds. Chromium(VI) Handbook; CRS Press: Boca Raton, FL, 2005.

(18) Ball, J. W.; Izbicki, J. A. Occurrence of hexavalent chromium in ground water in the western Mojave Desert, California. Appl. Geochem. 2004, 19, 1123-1135.

(19) Gonzalez, A. R.; Ndung'u, K.; Flegal, A. R. Natural occurrence of hexavalent chromium in the Aromas Red Sands Aquifer, California. Environ. Sci. Technol. 2005, 39, 5505-5511.

(20) Gough, L. P.; Meadows, G. R; Jackson, L. L.; Dudka, S. Biogechemistry of a highly serpentized chromite-rich ultra mafic area, Tehama County, California. U.S. Geol. Surv. Bull. 1989, 1901, 1-24.

(21) Manning, A. H.; Mills, C.; Morrison, J. M.; Ball, L. B. Insights into controls on hexavalent chromium in groundwater provided by environmental tracers, Sacramento Valley, California, USA. Appl. Geochem. 2015, 62, 186-199.

(22) Robertson, F. N. Hexavalent Chromium in the Ground Water in Paradise Valley, Arizona. Groundwater 1975, 13, 516-527.

(23) Robles-Camacho, J.; Armienta, M. A. Natural chromium contamination of groundwater of Leon Valley, Mexico. J. Geochem. Explor. 2000, 68, 167-181.

(24) Farías, S. S.; Casa, V. A.; Vázquez, C.; Ferpozzi, L.; Pucci, G. N.; Cohen, I. M. Natural contamination with arsenic and other trace elements in ground waters of Argentine Pampean Plain. Sci. Total Environ. 2003, 309, 187-199.

(25) Bertolo, R.; Bourotte, C.; Hirata, R.; Marcolan, L.; Sracek, O. Geochemistry of natural chromium occurrence in a sandstone aquifer in Bauru Basin, São Paulo State, Brazil. Appl. Geochem. 2011, 26, 1353-1363.

(26) Fantoni, D.; Brozzo, G.; Canepa, M.; Cipolli, F.; Marini, L.; Ottonello, G.; Zuccolini, M. V. Natural hexavalent chromium in groundwaters interacting with ophiolitic rocks. Environ. Geol. 2002, 42, $871-882$.

(27) Kazakis, N.; Kantiranis, N.; Voudouris, K. S.; Mitrakas, M.; Kaprara, E.; Pavlou, A. Geogenic Cr oxidation on the surface of mafic minerals and the hydrogeological conditions influencing hexavalent chromium concentrations in groundwater. Sci. Total Environ. 2015, $514,224-238$.

(28) Oze, C.; Bird, C. D.; Fendorf, S. Genesis of hexavalent chromium from natural sources in soil and groundwater. Proc. Natl. Acad. Sci. U. S. A. 2007, 104, 6544-6549.

(29) North Carolina Department of Environmental Quality (NCDEQ). Well test information for residents near Duke Energy coal ash impoundments (https://deq.nc.gov/about/divisions/water-resources/ water-resources-hot-topics/dwr-coal-ash-regulation/well-testinformation-for-residents-near-duke-energy-coal-ash-impoundments) (accessed May 16, 2016).

(30) Meij, R. Trace elements behavior in coal fired power plants. Fuel Process. Technol. 1994, 39, 199-217. 
(31) Shah, P.; Strezov, V.; Prince, K.; Nelson, P. F. Speciation of As, $\mathrm{Cr}$, Se and $\mathrm{Hg}$ under coal fired power station conditions. Fuel 2008, 87, 1859-1869.

(32) Kingston, H. M. S.; Cain, R.; Huo, D.; Mizanur Rahman, G. M. Determination and evaluation of hexavalent chromium in power plant coal combustion by-products and cost-effective environmental remediation solutions using acid mine drainage. J. Environ. Monit. 2005, 7, 899-905.

(33) Darakas, E.; Tsiridis, V.; Petala, M.; Kungolos, A. Hexavalent chromium release from lignite fly ash and related ecotoxic effects. $J$. Environ. Sci. Health, Part A: Toxic/Hazard. Subst. Environ. Eng. 2013, 48, 1390-1398.

(34) Ruhl, L.; Vengosh, A.; Dwyer, G. S.; Hsu Kim, H.; Schwartz, G.; Romanski, A.; Smith, S. D. The impact of coal combustion residue effluent on water resources: A North Carolina example. Environ. Sci. Technol. 2012, 46, 12226-12233.

(35) Ruhl, L.; Dwyer, G. S.; Hsu-Kim, H.; Hower, J. C.; Vengosh, A. Boron and strontium isotopic characterization of coal combustion residuals: Validation of new environmental tracers. Environ. Sci. Technol. 2014, 48, 14790-14798.

(36) Harkness, J.; Sulkin, B.; Vengosh, A. Evidence for coal ash ponds leaking in the southeastern United States. Environ. Sci. Technol. 2016, $50,6583-6592$.

(37) Warner, N. R.; Jackson, R. B.; Darrah, T. H.; Osborn, S. G.; Down, A.; Zhao, K.; White, A.; Vengosh, A. Geochemical evidence for possible natural migration of Marcellus formation brine to shallow aquifers in Pennsylvania. Proc. Natl. Acad. Sci. U. S. A. 2012, 109, 11961-11966.

(38) Zaffiro, A.; Zimmerman, M.; Wendelken, S.; Smith, G.; Munch, D. U.S. EPA Method 218.7: Determination of hexavalent chromium in drinking water by ion chromatography with post-column derivatization and UV-visible spectroscopic detection. Office of Water (MLK140) EPA Document No. EPA 815-R-11-005; U.S. Environmental Protection Agency: Washington, DC, 2011.

(39) Davidson, G. R.; Bassett, R. L. Application of boron isotopes for identifying contaminants such as fly ash leachate in groundwater. Environ. Sci. Technol. 1993, 27, 172-176.

(40) Dreesen, D. R.; Gladney, E. S.; Owens, J. W.; Perkins, B. L.; Wienke, C. L.; Wangen, L. E. Comparison of levels of trace elements extracted from fly ash and levels found in effluent waters from a coalfired power plant. Environ. Sci. Technol. 1977, 11, 1017-1019.

(41) Brubaker, T. M.; Stewart, B. W.; Capo, R. C.; Schroeder, K. T.; Chapman, E. C.; Spivak-Birndorf, L. J.; Vesper, D. J.; Cardone, C. R.; Rohar, P. C. Coal fly ash interaction with environmental fluids: Geochemical and strontium isotope results from combined column and batch leaching experiments. Appl. Geochem. 2013, 32, 184-194.

(42) Chapman, M. J.; Cravotta, C. A.; Szabo, Z.; Lindsey, B. D. Naturally occurring contaminants in the Piedmont and Blue Ridge crystalline-rock aquifers and Piedmont Early Mesozoic basin siliciclastic-rock aquifers, eastern United States, 1994-2008. U.S. Geological Survey Scientific Investigation Report 5072; U.S. Geological Survey: Reston, VA, 2013.

(43) Winkel, L.; Berg, M.; Amini, M.; Hug, S. J.; Johnson, C. A. Predicting groundwater arsenic contamination in Southeast Asia from surface parameters. Nat. Geosci. 2008, 1, 536-542.

(44) Dicken, C. L.; Nicholson, S. W.; Horton, J. D.; Foose, M. P.; Mueller, J. A. L. Preliminary integrated geologic map databases for the United States. U.S. Geological Survey Open-File Report (2005-1323); U.S. Geological Survey: Reston, VA, 2005 (http://pubs.usgs.gov/of/ 2005/1323/) (accessed September 29, 2016).

(45) Southeast Coal Ash Impoundments, 2013. Southern Alliance for Clean Energy (http://www.southeastcoalash.org/) (accessed September 29, 2016). 